\title{
DISCUSSION, The DHHU Process
}

\author{
by E. A. March
}

The vacuum degassing unit being installed at the Midland works of the Crucible Steel Co. of America is of the same basic design as the unit described in the foregoing paper. Our melt shop consists of a single long building housing one 35-ton electric furnace, four 80 -ton electric furnaces, and nine 170 -ton stationary open hearths. Our degassing unit will be located on the furnace working floor between the electric furnaces and the open hearths. Ladles of steel will be brought under the degassing unit by means of a transfer car moving between the pit bay and the furnace bay of the building.

This unit, being constructed by the Lectromelt Furnace Div. of the McGraw-Edison Co., will be the first of its kind installed in the US. It will be a flexible unit capable of treating the complete product from any of the three furnace sizes found in our shop. The 170-ton open hearth ladles will rest directly on the ladle car, while the smaller electric furnace ladles will rest upon adapters to bring the metal line to the same height, regardless of which size ladle is being treated. Treated steel will be transferred back to the pit bay and teemed in the normal manner.

The vacuum vessel itself is $15 \mathrm{ft}$ max diam by 14 ft 9 in. high. The entire inner lining will be magnesite ( 93 pct $\mathrm{MgO}, 3$ pct $\mathrm{CaO}$ ). The nozzle will have refractory lining on both inner and outer surfaces. The inside diameter will be 25 in. There are five additions hoppers on top of the vessel, all capable of discharging ferro alloys into the vessel while under vacuum. There are two hoppers of $80 \mathrm{cu} f \mathrm{ft}$ capacity, two of $20 \mathrm{cu} \mathrm{ft}$ capacity, and one of $10 \mathrm{cu} \mathrm{ft}$ capacity. Within the hoppers, there are combinations of small chambers to allow precise heat chemistry adjustment. The vessel will raise and lower hydraulically, traveling about $6 \mathrm{ft}$ at a speed of about $20 \mathrm{ft}$ per min. During operation, normal movement is about $2 \mathrm{ft}$.

There is a graphite resistance rod approx $8 \mathrm{ft}$ long across the top of the furnace, supplied by 750 kva of single-phase power. The purpose of this rod is to maintain the temperature of the refractories at that of liquid steel and, therefore, to compensate partially for the heat loss during the process.

The vacuum will be achieved by means of a four-stage steam ejector rated at $130,000 \mathrm{cfm}$ of evolved gas at average density and $200^{\circ} \mathrm{F}$. In addition to this, a parallel evacuator permits initial pump-down in less than 30 sec. After use, the vessel is flooded within $15 \mathrm{sec}$ with $\mathrm{N}_{2}$, requiring about 10 $\mathrm{cu} \mathrm{ft}$ at $40 \mathrm{~atm}$.

E. A. MARCH is assistant works manager, Crucible Steel Co. of America, Midland Works. This discussion was presented at the 1960 AIME National Open Hearth Steel Convention.
The majority of our open hearth shop's product is in the range of 0.20 to 0.45 pct $C$ and in alloy grades. We expect to tap unblocked heats at carbons slightly higher than specification... move these to the degassing unit . . . and cycle the metal through the vacuum chamber where the $\mathrm{O}_{2}$ will react with the $\mathrm{C}$ to result in a violent boil and the concurrent removal of all gases. When degassing is completed, alloy additions will be made through the vessel during the last few cycles. Calculations, based upon the experience at Dortmund and upon our equipment capabilities, indicate that a total of 30 to 40 cycles will complete the process.

Interpretation of the paper's data concerning quality improvement is very difficult. We can only state that our examination of samples from Dortmund verifies the fact that there is a very definite improvement in non-metallic inclusion count through degassing. Oxides are slightly reduced in number, considerably reduced in maximum size, and their distribution is somewhat more uniform. Silicates are reduced to an even greater degree. Even sulfides seem to be redistributed so that, while sulphur content remains essentially unchanged, the sulfides become smaller, more numerous, and more uniformly distributed. The open hearth product plus degassing is expected to show a significant improvement over present product.

Having within Crucible the capability of producing steel by the open hearth, electric arc, air induction, vacuum induction, and vacuum arc methods, we are not yet certain just where vacuum-degassed steel will fit into the picture. We do not know which of these processes will be augmented by vacuum degassing, which will be supplemented, or which will be replaced. European experience to date has been entirely with open hearth products. It seems ideal for these. At the next Open Hearth Conference, we will be able to present the results of our work.

Please bear in mind that our objective is somewhat different from that of those firms which have installed stream degassing units We do not have a major problem requiring hydrogen removal in our products. We must achieve quality improvements in non-metallic inclusion ratings, magnaflux ratings, and, possibly, in transverse properties. This unit seems to possess the requisite characteristics, since we can degas and then make alloy additions. There are interesting possibilities of using this equipment to produce carburizing grades, alloy grades, and even traditionally electric furnace grades in the open hearth. 